\title{
Environmental Efficiency and Urban Ecology
}

\author{
Ching-Yu Chen, Jwu-Rong Lin* \\ Department of International Business, Tunghai University, Taiwan \\ Email: *jrlin@thu.edu.tw
}

How to cite this paper: Chen, C.-Y., \& Lin, J.-R. (2021). Environmental Efficiency and Urban Ecology. Theoretical Economics Letters, 11, 422-446. https://doi.org/10.4236/tel.2021.113028

Received: April 10, 2021

Accepted: May 31, 2021

Published: June 3, 2021

Copyright $\odot 2021$ by author(s) and Scientific Research Publishing Inc. This work is licensed under the Creative Commons Attribution International License (CC BY 4.0).

http://creativecommons.org/licenses/by/4.0/

\begin{abstract}
Evaluating organizational efficiency involves measuring outcomes, such as revenues, value of goods and services produced, productivity, etc. However, a sustainable environment requires not only economic outcomes but also good quality of life in an area. Therefore, this research proposes a balanced assessment to evaluate environmental efficiency from the perspectives of urban ecology. We first adopted the bad output data envelopment analysis to evaluate the efficiency of a metropolitan area followed by a biotope area factor to assess the ecological effectiveness of an area. Next, a censored regression model evaluates the relationship between environmental efficiency and biotope area factor. The empirical studies were conducted in Taichung, Taiwan. Empirical results suggest that typical efficiency evaluation of a metropolitan area is significantly overrated because it excludes external diseconomies such as $\mathrm{CO}_{2}$ emissions which have a profound impact on the environment. The regression results indicate that environmental efficiency and Taiwan biotope area factor are complementary and can be improved simultaneously while $\mathrm{CO}_{2}$ emission reduction is at present. We also show that current utilization of area for non-agriculture and human activities poses a negative impact on Taiwan biotope area factor.
\end{abstract}

\section{Keywords}

Bad Output Data Envelopment Analysis, Biotope Area Factor, External Diseconomies, Technical Efficiency, $\mathrm{CO}_{2}$ Emissions, Sustainability

\section{Background}

The pursuit of economic development, over-consumption, and global climate change has caused disruptive damages to the earth we live on and many others inhabit the same space with us. Especially environmental issues like dengue fever, avian influenza, heat island effect, endocrine disrupting chemicals, etc. have become normality in urban areas (NOAA, 2018). Many environmentally friendly 
policies are being adopted and executed, for examples, green roof (Mills \& Rott, 2020; Thuring \& Grant, 2016), green building (Wang et al., 2014), ecologic passageway (Peng et al., 2017), etc. However, the effectiveness of these policies in improving urban ecology remains to be investigated. Therefore, this study aims to investigate environmental efficiency and urban ecology from regional (metropolitan) level. We first evaluated efficiency by the bad output data envelopment analysis (please refer to Tone, 2001, 2002, 2003; Zhou et al., 2013) in which we incorporated $\mathrm{CO}_{2}$ emissions in the empirical studies. Second, in evaluating the ecological effectiveness of a metropolitan area in Taiwan, we consulted el-Baghdadi and Desha (2017) and the Berlin Biotope Area Factor (BAF) and established Taiwan biotope area factor (TBAF) as a proxy variable. Finally, we developed a statistical regression model to test the relevance between environmental efficiency and Taiwan biotope area factor. The main contribution of this research lies in the inclusive of external diseconomies and urban ecology in the evaluation of efficiency. In the next section, we will review literature related to efficiency evaluation and urban ecology.

\section{Literature Review}

Typically, in evaluating the efficiency or productivity of a decision-making unit (DMU), data envelopment analysis (DEA) or stochastic frontier analysis are adopted by many researchers and therefore, many applications and modifications are extended from the classic DEA model in the literature. For examples, Fare et al. (1989) provided a mathematical methodology for efficiency measurements to accommodate both desirable and undesirable outputs. Lozano and Gutiérrez (2011) utilized a slack-based measure data envelopment analysis to evaluate the efficiency of 39 airports in Spain with two undesirable outputs, percentage of delayed flights and average conditional delay of delayed flights. The results were able to distinguish benchmark airports and identified slacks in outputs for inefficient airports to improve. Chang et al. (2013) discussed efficiency for the transportation industry in China with concerns of energy consumption and environmental pollution. The input was fuel uses from different transportation systems and the output included $\mathrm{CO}_{2}$ emissions and energy consumptions. The empirical results suggested that the transportation industry in China lacks eco-efficient transportation systems and the industry was inefficient environmentally. Bai et al. (2018) utilized the super-efficiency data envelopment analysis model to assess urban eco-efficiency. They utilized principal component analysis to quantify level of urbanization of 281 cities during 2006-2013 in China. Results of a spatial econometric analysis indicated that there existed an $\mathrm{N}$-shaped relationship between urbanization and urban eco-efficiency. Our research logic follows that of Bai et al. (2018) but we focus on urban ecology and biotope area factor instead of urbanization. Liu et al. (2018) calculated the Malmquist-Luenberger index to examine the productivity of 225 decision making units across industries in the Pearl River Delta region, China. Results suggested that $66.9 \%$ of compa- 
nies developed with improved productivity and $40 \%$ developed in a green way. Zhang et al. (2018) calculated $\mathrm{CO}_{2}$ emissions from nine energy emissions in the construction industry in China and utilized a 3-stage DEA model to measure technical efficiency and the relationship between the impact of environmental regulations and technical efficiency. Our research adopted this bad output DEA formulations but different from Zhang et al. (2018), we obtained the water and electricity consumptions to compute the level of $\mathrm{CO}_{2}$ emissions of a city. Wang et al. (2019) measured the total factor carbon emission performance (TFCP) and the carbon emission mitigation potential (CMP) in the Beijing-Tianjin-Hebei (BTH) region from 2010 to 2016 by a Translog stochastic frontier approach. Rahman et al. (2019) utilized a meta-frontier approach to compare efficiencies across different aquaculture production environments. Literature regarding to urban ecology we refer to the followings that are most relevant to our research. Forman and Godron (1986) classified landscape into patch, corridor, and matrix. The terminology landscape ecology was then used commonly to refer to the study of spatial structure, landscape architecture, urban planning, etc. More literature on landscape ecology please refers to Dramstad et al. (1996) and Forman (2014). Starting from the 1990s Berlin started to use biotope area factor (BAF), an index to measure the ecological score of a surface based on the land use plan, Senate Department for Urban Development, 1990. The higher BAF score, the better protection of biotopes, species, and the land. The application of BAF in academia and practices started to spread to the rest of Germany (Sukopp \& Weiler, 1988; Yilmaz et al., 2010) and around the world.

Main contributions of our research to the literature includes: 1) we estimated and compared the technical and environmental efficiencies of a metropolitan area by data envelopment analysis with bad output, carbon dioxide emissions; 2 ) we established a biotope area factor specifically to evaluate the ecological effectiveness of metropolitan areas in Taiwan from the perspective of urban ecology; and; 3) utilizing scatter charts and censored regression model to investigate the relationship between environmental efficiency which incorporates economic, environmental and social factors and Taiwan biotope area factor. The remainder of this paper is organized as follows: Section 3 presents the construction of mathematical models to evaluate efficiency and Taiwan biotope area factor; Section 4 provides the empirical results and discussions; finally, conclusions and constraints of the study are presented in Section 5.

\section{Methods}

Section 3.1 introduces the typical technical efficiency DEA approach which focuses on the number of desirable outputs generated by allocated input resources. Considering the sustainable development of a metropolitan area, it is important to include environmental/hazardous outputs which have a tremendous impact for a longer run than economic outputs. Therefore, a slack-based measure (SBM) DEA model is introduced to accommodate bad output in Section 3.2. Section 3.3 
presents a biotope area factor evaluation to measure the ecological effectiveness customized to the ecosystem in Taiwan.

\subsection{Measuring Technical Efficiency}

Charnes et al. (1978) developed one of the well-known models for evaluating technical efficiency known as the Charnes, Cooper and Rhodes (1978) (CCR) DEA model. The model specifications are given as follows. We assume that inputs and outputs exhibit constant returns to scale and define a decision-making unit, $\mathrm{DMU}_{i}, i=1-N$. Each $\mathrm{DMU}_{\mathrm{i}}$ possesses an input vector $x_{i}=\left(x_{1 i}, \cdots, x_{k i}\right)$ and produces an output vector $y_{i}=\left(y_{1 i}, \cdots, y_{m i}\right) . X=\left[x_{1}, \cdots, x_{N}\right]$ and $Y=\left[y_{1}, \cdots, y_{N}\right]$ represent the input and output matrices of all DMUs respectively. Let $\theta$ be the technical efficiency of a DMU and $\lambda$ is the weights vector. Thus, the linear programming model to evaluate the technical efficiency of a DMU can be given as:

$$
\begin{gathered}
\theta^{*}=\min _{\lambda} \theta \\
\text { s.t. } \quad y_{i} \leq Y \lambda \\
\theta x_{i} \geq X \lambda \\
\lambda \geq 0,
\end{gathered}
$$

where $\theta$ lies between $(0,1)$. If $\theta=1$, the technical efficiency of the DMU under evaluation is on the efficiency frontier. As $\theta$ approaches 0 , we consider the DMU operating inefficiently.

\subsection{Measuring Environmental Efficiency}

To evaluate the environmental efficiency that incorporates undesirable outcomes requires adjustments to the previous CCR model. Tone $(2001,2002,2003)$ introduced slacks-based measure (SBM) DEA model. Related literature includes Chuang and Wu (2006), Taskin and Zaim (2001), Seiford and Zhu (2002), Portela et al. (2004), and Wang et al. (2013). The advantage of SBM models is that it enables the consideration of both desirable and undesirable outputs and computes ratios of input and output inefficiencies in a linear programming model without additional data conversion. To illustrate the SBM model with undesirable/bad outputs, we follow the same notations as in Section 3.1 except that the output vector $y_{i}=\left(y_{1 i}, \cdots, y_{m i}\right)$ is now divided into a good output vector $y_{i}^{g} \in R^{m 1}$ and a bad output vector $y_{i}^{b} \in R^{m 2}$, where $m 1+m 2=m$. Thus, the output matrices become $Y^{g}=\left[y_{1}^{g}, \cdots, y_{N}^{g}\right] \in R^{m 1 \times N}$, and $Y^{b}=\left[y_{1}^{b}, \cdots, y_{N}^{b}\right] \in R^{m 2 \times N}$. Therefore, the production possibility set is given by

$$
P=\left\{\left(x, y^{g}, y^{b}\right) \mid x \geq X \lambda, y^{g} \leq Y^{g} \lambda, y^{b} \leq Y^{b} \lambda, \lambda \geq 0\right\}
$$

Let $\bar{s}, s^{g}$, and $s^{b}$ represents the slack vector of input excess, good output shortfall, and bad output excess respectively. Then, the efficiency of a certain $\mathrm{DMU}_{0}$ in the SBM model incorporating bad outputs can be written as, 


$$
\begin{gathered}
\rho^{*}=\min \frac{1-\frac{1}{k} \sum_{i=1}^{k} \frac{s_{i}^{-}}{x_{i 0}}}{1+\frac{1}{m 1+m 2}\left(\sum_{r=1}^{m 1} \frac{s_{r}^{g}}{y_{r 0}^{g}}+\sum_{r=1}^{m 2} \frac{s_{r}^{b}}{y_{r 0}^{b}}\right)} \\
\text { s.t. } \quad x_{0}=X \lambda+s^{-}, \\
y_{0}^{g}=Y^{g} \lambda-s^{g}, \\
y_{0}^{b}=Y^{b} \lambda+s^{b}, \\
\lambda, s^{-}, s^{g}, s^{b} \geq 0 .
\end{gathered}
$$

Suppose the optimal solution is $\left(\lambda^{*}, s^{-*}, s^{g^{*}}\right.$ and $\left.s^{b *}\right)$. When $s^{-*}=s^{g *}=s^{b *}=0$, it means that $\rho^{*}=1$ and the $\mathrm{DMU}_{0}$ is fully efficient. If $\rho^{*}<1$, the $\mathrm{DMU}_{0}$ is not utilizing its resources efficiently. For $\mathrm{DMU}_{0}$ to become more efficient, it must reduce its inputs, bad output or increase good outputs. Let $\hat{x}_{0}, \hat{y}_{0}^{g}, \hat{y}_{0}^{b}$ be the project point onto the efficiency frontier and we then calculate the room for improvement in efficiency for $\mathrm{DMU}_{0}$ using the following equation:

$$
\hat{x}_{0}=x_{0}-s^{-*}, \hat{y}_{0}^{g}=y_{0}^{g}+s^{g *}, \hat{y}_{0}^{b}=y_{0}^{b}-s^{b *} .
$$

\subsection{Measuring Ecological Effectiveness in Taiwan: Taiwan Biotope Area Factor}

To construct Taiwan biotope area factor, we consulted with Berlin Biotope Area Factor (BAF) which is based on concept of landscape ecology. BAF is a system developed by the Berlin administration to evaluate the impact of urban developments with an aim of preserving and creating living places among living things (Senate Department for Urban Development, 1990). BAF reflects the ratio of the ecologically effective surface area to the total land area. Different types of surfaces are weighted according to their ecologically effective value (weighting factor). The more permeable to water and air or the more plant growth of a surface, the higher the weighting factor is. Let $A_{i}$ denote the land area and $w_{i}$ be the weighting factor for surface type $i$. Thus, the ecologically effective area (EEA) of surface type $i$ is calculated in Equation (12) and the biotope area factor (BAF) for an area of $n$ different types of surfaces is given by Equation (13).

$$
\begin{gathered}
\mathrm{EEA}_{i}=A_{i} * w_{i} \\
\mathrm{BAF}=\sum_{i=1}^{n} \frac{A_{i} w_{i}}{\sum A_{i}}
\end{gathered}
$$

Based upon the above Berlin BAF calculation, we obtained a complete spatial database of photogrammetry, a land use investigation report of Taiwan and utilized a Geography Information System to determine types of land uses, vegetation areas, water body, geographic information, etc. in Taichung city in 2017. Detailed sources of data are specified in Section 4. Furthermore, a Delphi questionnaire of 20 experts in the field of urban ecology was conducted and a con- 
sensus on ecological minimum standards was reached for Taichung's landscape plans and spatial structures. We used Berlin BAF, Seattle Green Factor (GF) and similar landscaping quality evaluation systems in the USA as references and classified land areas of Taiwan into four groups with 13 surface types and each surface type has an assigned weighting indicating its contribution to developing the ecosystem concluded by the expert questionnaire. Surface type classification and weighting factors are listed in Table 1 . Thus, TBAF score is computed using the following equation:

$$
\mathrm{TBAF}=\sum W_{i} X_{i}+\sum W_{N} A_{N}+\operatorname{adj} .
$$

In Equation (14), $X_{i}$ denotes the area for surface type $i, i=(A, \cdots, M)$ as listed in Table 1 and $W_{i}$ represents the weighting assigned to surface type $i$. $W_{N}$ is the weighting assigned to the interaction variable $A_{N}, N=(D, I, \lambda)$ and adj is the adjustment made to ensure that the TBAF score lies between 0 and 1 . The higher the TBAF value of an area, the better quality of the plant and animal habitats as well as the better the residential environment in that area.

\section{Empirical Results and Discussions}

\subsection{Data}

Our proposed model to evaluate environmental efficiency and TBAF was applied to Taichung city, located in Central Taiwan, comprising 29 administrative districts. It is the second largest metropolitan in Taiwan with an area of $2215 \mathrm{~km}^{2}$. Figure 1 illustrates current space allocation of Taichung city. It is observed that

Table 1. Taiwan biotope area factor.

\begin{tabular}{cccc}
\hline Item & \multicolumn{2}{c}{ Surface Type } & Weighting \\
\hline A & Paving surfaces & Impermeable & 1.4 \\
B & & Permeable & 4.4 \\
C & Horticulture & Unconnected to soil below & 3.9 \\
D & & Connected to soil below & 4.9 \\
E & & Ground cover plants & 4.3 \\
F & Vegetation & Shrubs & 4.5 \\
G & & Small trees & 3.7 \\
H & & Medium trees & 6.1 \\
I & & Large trees & 7.0 \\
J & & Multi-layer planting & 6.4 \\
K & Bioretention & Greenery on rooftop & 4.3 \\
L & & Green walls & 3.4 \\
M & Interaction Variable & Rainwater infiltration & 5.4 \\
AD & Interaction Variable & -2.3694 & \\
AI & Interaction Variable & 1.7121 & \\
AJ & & -2.6144 & \\
\hline
\end{tabular}

Data is prepared by this study. 


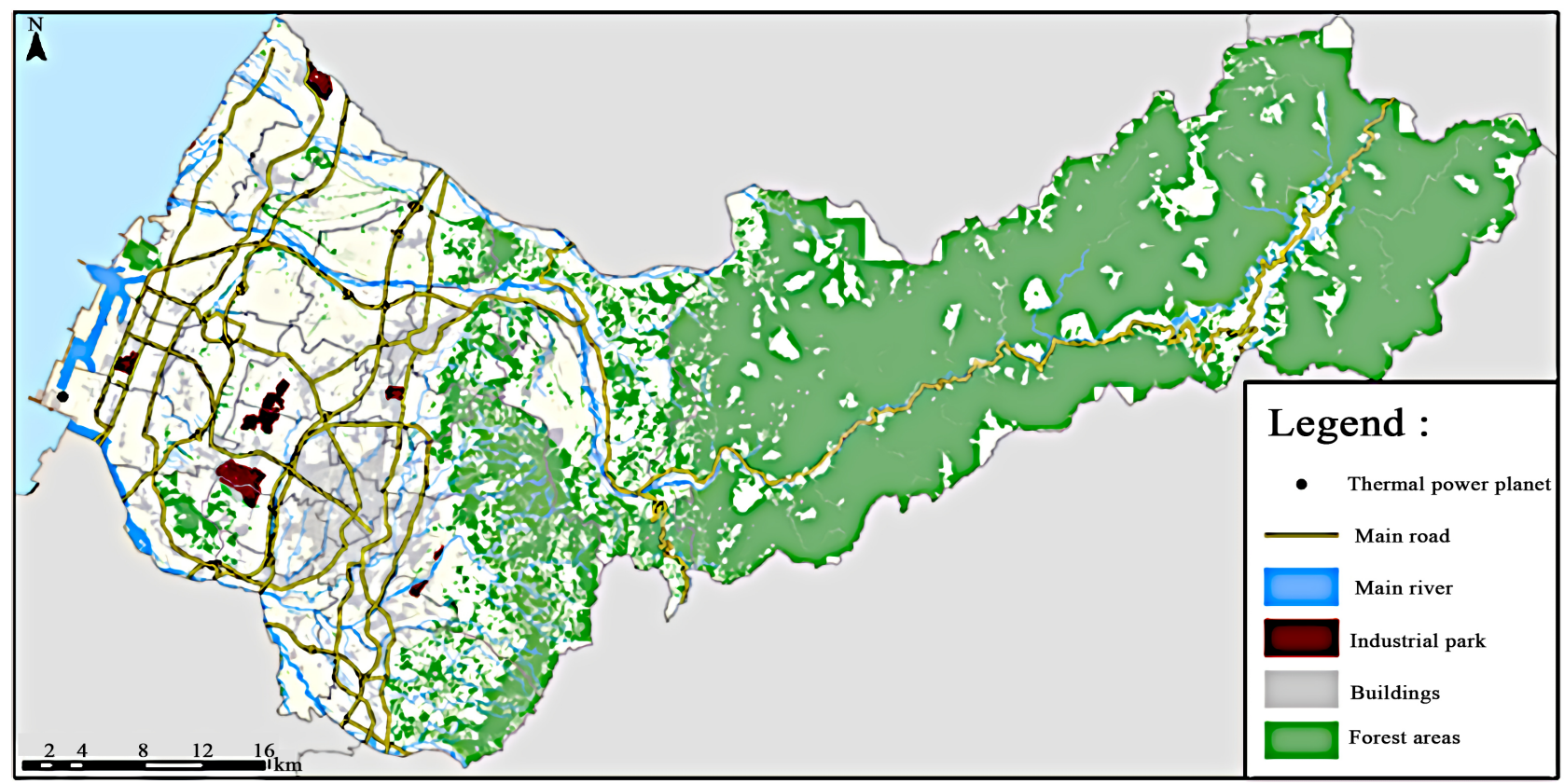

Figure 1. Space allocation of Taichung City, Taiwan.

the east part of Taichung is covered by abundant forests and the west is mostly composed of urban areas. The spatial database of aerial photograph and the 2017 land use investigation report are obtained from National Land Surveying and Mapping Center, Ministry of the Interior, Taiwan.

To reflect the environmental efficiency, we obtained data from different aspects of the city: environmental, economic, and social factors. Economic factors include 1) labor, 2) area for agriculture and forest uses, 3) area for other use which includes commercial, residential, industrial areas, and public facilities, and 4) value-added (production value). $\mathrm{CO}_{2}$ emissions and Taiwan biotope area factor values are the two environmental factors in the study. Electricity and water consumptions are used to compute the level of carbon dioxide emissions. As this research was conducted, the average $\mathrm{CO}_{2}$ emissions were $0.53 \mathrm{kgCO}_{2} \mathrm{e}$ per $\mathrm{kWh}$ of electricity consumption and $0.152 \mathrm{kgCO}_{2} \mathrm{e}$ per $\mathrm{M}^{3}$ of water consumption in 2016 based on data provided by the Bureau of Energy, Ministry of Economic Affairs, Taiwan. Therefore, Equations (15) \& (16) shows the computation of $\mathrm{CO}_{2}$ emissions from the electricity and water consumption of Taichung respectively and Equation (17) sums up the total $\mathrm{CO}_{2}$ emissions of an area.

$$
\begin{gathered}
\mathrm{CO}_{2} \mathrm{E}=0.53 * \text { electrivity consumption }(\mathrm{kWh}) \\
\mathrm{CO}_{2} \mathrm{~W}=0.152 * \text { water consumption }\left(\mathrm{M}^{3}\right) \\
\mathrm{CO}_{2}=\mathrm{CO}_{2} \mathrm{E}+\mathrm{CO}_{2} \mathrm{~W}
\end{gathered}
$$

However, 8 out of 29 districts in Taichung did not have independent data regarding water consumption. Thus, the total water consumption was distributed to districts according to their percentages of population. Social factors include: 1) living assistance for disadvantaged children and youth, 2) living assistance for 
people with disabilities, 3) living assistance for seniors, and 4) social assistance for low- to middle-income households. The last variable in the model is Taichung city's budget for 29 districts at the end of 2016. Table 2 presents details in variable notations and data sources.

Table 2. Variable notations.

\begin{tabular}{|c|c|c|c|c|}
\hline Category & Variable & Notation & Unit & Data Source \\
\hline \multirow{4}{*}{ Economic } & Labor & $\mathrm{L}$ & persons & $\begin{array}{l}2016 \text { Industry and Service } \\
\text { Census Report from } \\
\text { Directorate-General of } \\
\text { Budget, Accounting, and } \\
\text { Statistics, Executive Yuan, } \\
\text { Taiwan }\end{array}$ \\
\hline & $\begin{array}{c}\text { Area for Agriculture } \\
\text { and Forest }\end{array}$ & AAF & $\mathrm{km}^{2}$ & $\begin{array}{l}\text { Dept. of Life Science, } \\
\text { Tunghai University }\end{array}$ \\
\hline & Area for Other Use & $\mathrm{AO}$ & $\mathrm{km}^{2}$ & $\begin{array}{c}\text { Dept. of Life Science, } \\
\text { Tunghai University }\end{array}$ \\
\hline & Value-Added & VA & $\begin{array}{l}\text { Million } \\
\text { NT dollars }\end{array}$ & $\begin{array}{l}2016 \text { Industry and Service } \\
\text { Census Report from } \\
\text { Directorate-General of } \\
\text { Budget, Accounting, and } \\
\text { Statistics, Executive Yuan, } \\
\text { Taiwan }\end{array}$ \\
\hline \multirow{4}{*}{ Environmental } & $\mathrm{CO}_{2}$ Emissions & $\mathrm{CO}_{2}$ & $\mathrm{KgCO}_{2} \mathrm{e}$ & $\begin{array}{c}\text { Bureau of Energy, } \\
\text { Ministry of Economic } \\
\text { Affairs, Taiwan }\end{array}$ \\
\hline & $\begin{array}{c}\text { Electricity } \\
\text { Consumption }\end{array}$ & QE & $\mathrm{kWh}$ & $\begin{array}{c}\text { Taiwan Power Company, } \\
\text { Dept. of Household } \\
\text { Registration, and } \\
\text { Environmental } \\
\text { Protection Administration }\end{array}$ \\
\hline & Water Consumption & QW & $\mathrm{M}^{3}$ & Taiwan Water Corporation \\
\hline & $\begin{array}{c}\text { Taiwan Biotope } \\
\text { Area Factor }\end{array}$ & TBAF & & $\begin{array}{l}\text { Dept. of Life Science, } \\
\text { Tunghai University }\end{array}$ \\
\hline \multirow{4}{*}{ Social } & $\begin{array}{l}\text { Living Assistance for } \\
\text { Disadvantaged } \\
\text { Children and Youth }\end{array}$ & $\mathrm{S} 1$ & Persons & \multirow{4}{*}{$\begin{array}{c}\text { Social Affairs Bureau, } \\
\text { Taichung City } \\
\text { Government }\end{array}$} \\
\hline & $\begin{array}{c}\text { Living Assistance for } \\
\text { People with Disabilities }\end{array}$ & $\mathrm{S} 2$ & Persons & \\
\hline & $\begin{array}{l}\text { Living Assistance } \\
\text { for Seniors }\end{array}$ & $\mathrm{S} 3$ & Persons & \\
\hline & $\begin{array}{c}\text { Social Assistance for } \\
\text { Low-to Middle-Income } \\
\text { Households }\end{array}$ & $\mathrm{S} 4$ & Persons & \\
\hline Budget & $\begin{array}{c}\text { City } \\
\text { Government Budget }\end{array}$ & BUG & $\begin{array}{l}\text { Thousand } \\
\text { NT dollars }\end{array}$ & $\begin{array}{l}\text { Budget, Accounting and } \\
\text { Statistics Office of } \\
\text { Taichung City Government }\end{array}$ \\
\hline
\end{tabular}




\subsection{Comparison of Technical and Environmental Efficiencies}

This section presents our results from the SBM data envelopment analysis of Equation (6) by DEA-Solver 8.0. Specifically, we compare the efficiency of SBM without $\mathrm{CO}_{2}$ emissions (technical efficiency) and with $\mathrm{CO}_{2}$ emissions (environmental efficiency). Input variables are labor (L) and area for other use (AO) which includes areas for industrial, commercial, and residential areas, and public facilities. Output variables include value-added (VA), $\mathrm{CO}_{2}$ emissions $\left(\mathrm{CO}_{2}\right)$ calculated from electricity $(\mathrm{QE})$ and water $(\mathrm{QW})$ consumption, total number of people received social assistance per dollar (SW), and city government budget (BUG). SW is a collective index to represent social welfare output per dollar. SW $=(\mathrm{S} 1+\mathrm{S} 2+\mathrm{S} 3+\mathrm{S} 4) / \mathrm{BUG}$. Before executed the SBM data envelopment analysis, a statistical test was conducted to examine whether our variables satisfy monotonically increasing property which is a necessary condition to perform DEA models. Table 3 shows the correlation coefficients between input and output variables. It is observed that variables were all positively related except for the relation between AO and SW which was not significant statistically. All variables in our modeling displayed a monotonically increasing property which justified the use of DEA models in the empirical study.

Table 4 compares SBM results of technical efficiency (without $\mathrm{CO}_{2}$ emissions) and that of environmental efficiency (with $\mathrm{CO}_{2}$ emissions) in Taichung. It is observed that the median of technical efficiency of the sample is 0.6221 which is higher than the median of environmental efficiency 0.4664 . It reveals that without considering the external diseconomies $\left(\mathrm{CO}_{2}\right.$ emissions) derived from economic activities, productivity is likely to be overestimated. Meanwhile, the average environmental efficiency of the sample is 0.5813 indicating a $42 \%$ room of improvement is required to reach full efficiency. Appendix Table A1 shows slacks in each of the variables and room of improvement for all 29 districts in the sample, among them 21 were environmentally inefficient districts. Furthermore, a benchmark district means that a district has an efficiency value of one and the district is fully efficient in utilizing input resources. In the sample, Cental, Dengshi, Houli, Tanzi, Xinshe, Shigang, Daan, and Longjing districts are environmentally efficient benchmark districts. These districts are mostly covered by residential

Table 3. Table of correlation coefficients.

\begin{tabular}{cccccc}
\hline & $\mathrm{L}$ & $\mathrm{AO}$ & $\mathrm{VA}$ & $\mathrm{CO}_{2}$ & $\mathrm{SW}$ \\
\hline $\mathrm{L}$ & 1.0000 & $0.4438^{* *}$ & $0.9325^{* * *}$ & $0.8246^{* * *}$ & $0.6695^{* * *}$ \\
$\mathrm{AO}$ & $0.4065^{* *}$ & 1.0000 & $0.4645^{* *}$ & $0.4833^{* * *}$ & 0.1488 \\
$\mathrm{VA}$ & $0.9281^{* * *}$ & $0.4006^{* *}$ & 1.0000 & $0.9404^{* * *}$ & $0.5030^{* * *}$ \\
$\mathrm{CO}_{2}$ & $0.7710^{* * *}$ & $0.3603^{*}$ & $0.9211^{* * *}$ & 1.0000 & $0.3857^{* *}$ \\
$\mathrm{SW}$ & $0.5377^{* * *}$ & 0.2688 & $0.3909^{* *}$ & 0.2096 & 1.0000 \\
\hline
\end{tabular}

Note: The upper right corner and the lower left corner are the Spearman's and Pearson's coefficients, respectively. ${ }^{* *},{ }^{* *}$ and ${ }^{\star}$ denotes significance at the $1 \%, 5 \%$, and $10 \%$ levels, respectively. Data is prepared by this study. 
Table 4. Comparison of technical and environmental efficiencies.

\begin{tabular}{ccccccc}
\hline & Max. & Min. & Average & Median & $\begin{array}{c}\text { Number of } \\
\text { Benchmarks }\end{array}$ & $\begin{array}{c}\text { The } \\
\text { Median Test }\end{array}$ \\
\hline Technical Efficiency & 1 & 0.3664 & 0.6807 & 0.6221 & 6 & $4.4403^{* * *}$ \\
Environmental Efficiency & 1 & 0.2309 & 0.5813 & 0.4664 & 8 & \\
\hline
\end{tabular}

Note: The median test is the $c^{2}$ test with degree of freedom $=1$ and ${ }^{* * *}$ represents significance at the $1 \%$ level. Data is prepared by this study.

and agriculture areas that are of low inputs, low value-added, and relatively low $\mathrm{CO}_{2}$ emissions. The poorest performance in environmental efficiency appears in Nantun district. In terms of input variables, it is noted that 11 out of 21 inefficient districts are efficient in labor productivity. It is suggested that $\mathrm{AO}$ needs to be reduced to a greater extent than labor and that the way Taichung utilizes area for industrial, commercial, and residential uses is critical in enhancing the environmental efficiency. Social welfare is another area that requires a considerable improvement. On the other hand, the output level of value-added is satisfying. Only the east district requires a $25.23 \%$ increase in efficiency. Furthermore, all districts require a considerable reduction in the level of $\mathrm{CO}_{2}$ emissions. Dajia district needs the least of $3.22 \%$ and Qingshui district needs the most reduction of $50.18 \%$ in $\mathrm{CO}_{2}$ emissions. To conclude results of the SBM analysis, inefficient utilization of non-agriculture or non-forest areas, excessive $\mathrm{CO}_{2}$ emissions, and insufficient social welfare are accounted for the low environmental efficiency in Taichung.

\subsection{Results of Taiwan Biotope Area Factor and Its Relationship with Environmental Efficiency}

Figure 2 exhibits a histogram of the TBAF results of 29 districts in Taichung. The average TBAF value is 0.414 , the median value is 0.365 and most districts has a TBAF value ranging between 0.2 and 0.6 , indicating that Taichung's ecological value is considerably low. In other words, the existing landscape of the city is unfavorable to the animal and plant habitat and the residential environment and, of course, the ecosystem does not support sustainability. Heping district, however, outperformed the rest of the districts with $\mathrm{TBAF}=0.9$. It is in the west part of Taichung where it is mostly forest and agriculture areas. The lowest TBAF value is in Nantun district which also has the lowest value in environmental efficiency as shown in Appendix Table A1. The environmental quality of the district is compromised by the flourishing economic activity since value added in Nantun district is fully efficient.

Scatter plots in Figures 3-5 show the relations between pairs of TBAF, EE, $\mathrm{CO}_{2}$, and agriculture and forest area (AAF). We observe from Figure 3 that $\mathrm{EE}$ and TBAF are positively related and those districts with low values in both EE and TBAF are highly urbanized districts. Figure 4 displays the negative relation between $\mathrm{CO}_{2}$ and $\mathrm{EE}$ as well as between $\mathrm{CO}_{2}$ and TBAF suggesting that $\mathrm{CO}_{2}$ 


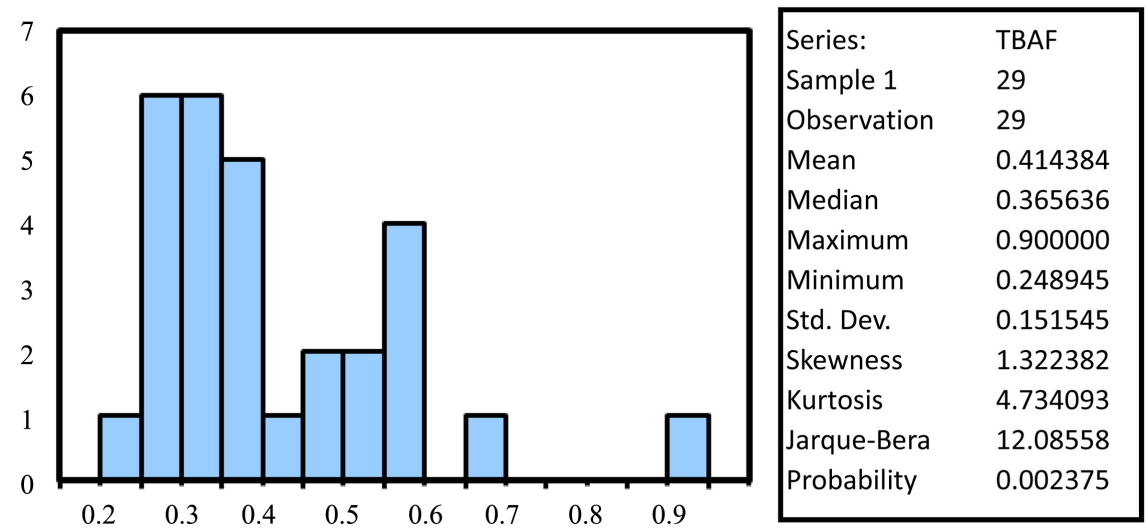

Figure 2. Histogram of Taiwan biotope area factor.

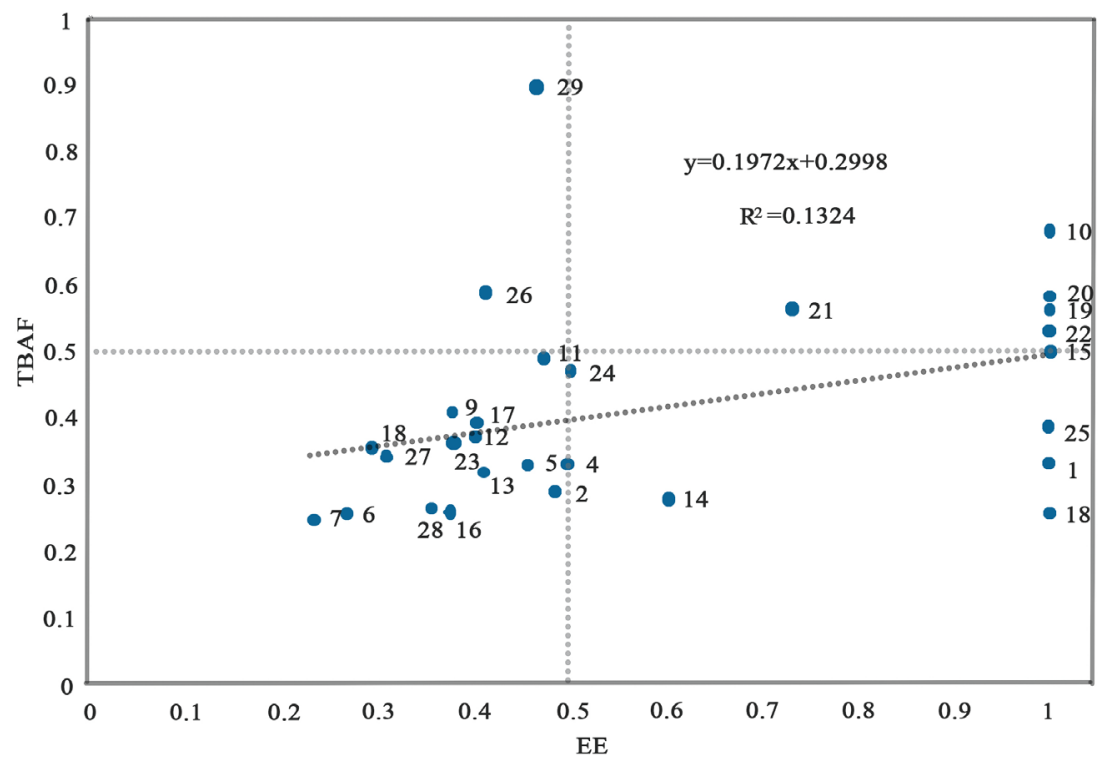

\begin{tabular}{cccccccccc}
\hline No. & District & No. & District & No. & District & No. & District & No. & District \\
\hline 1 & Central & 7 & Nantun & 13 & Shalu & 19 & Xinshe & 25 & Longjing \\
2 & East & 8 & Beitun & 14 & Wuqi & 20 & Shigang & 26 & Wufeng \\
3 & South & 9 & Fengyuan & 15 & Houli & 21 & Waipu & 27 & Taiping \\
4 & West & 10 & Tungshi & 16 & Shengang & 22 & Daan & 28 & Dali \\
5 & North & 11 & Dajia & 17 & Tanzi & 23 & Wuri & 29 & Heping \\
6 & Xitun & 12 & Qingxui & 18 & DaYa & 24 & DaDu & &
\end{tabular}

Figure 3. Scatter plot between EE and TBAF.

emissions threat not only the ecosystem but efficiency. Figure 5 shows that agriculture and forest area is positively related to TBAF; however, it is negatively related to EE. It can be inferred that agriculture and forest area provides green areas and promotes the ecological value of an area, but the current economic or social output of the area is insufficient from the perspective of sustainability that simultaneously considers economic, social, and environmental factors. 


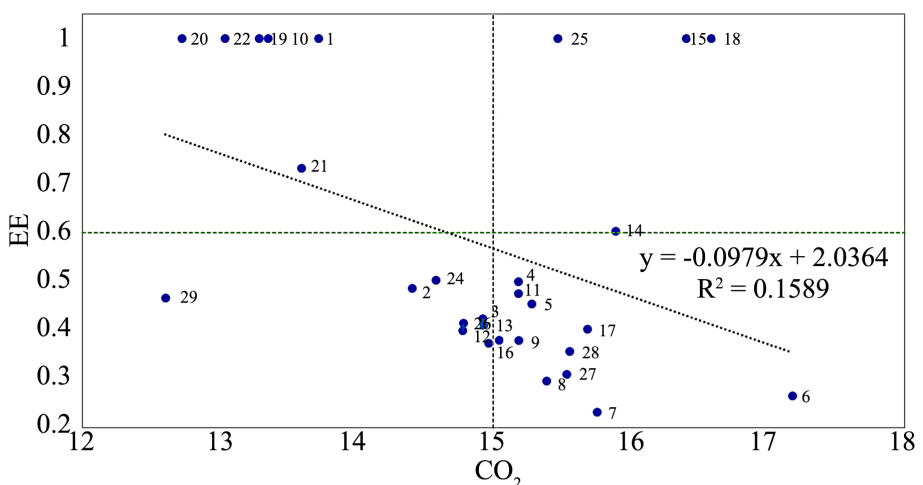

(a)

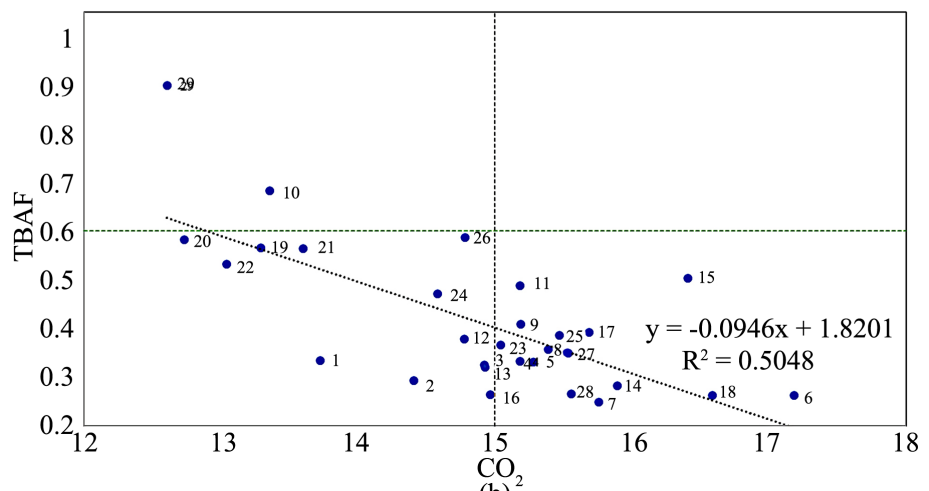

(b)

Figure 4. Scatter plots between $\mathrm{CO}_{2}$ and $\mathrm{EE}$ and between $\mathrm{CO}_{2}$ and TBAF.

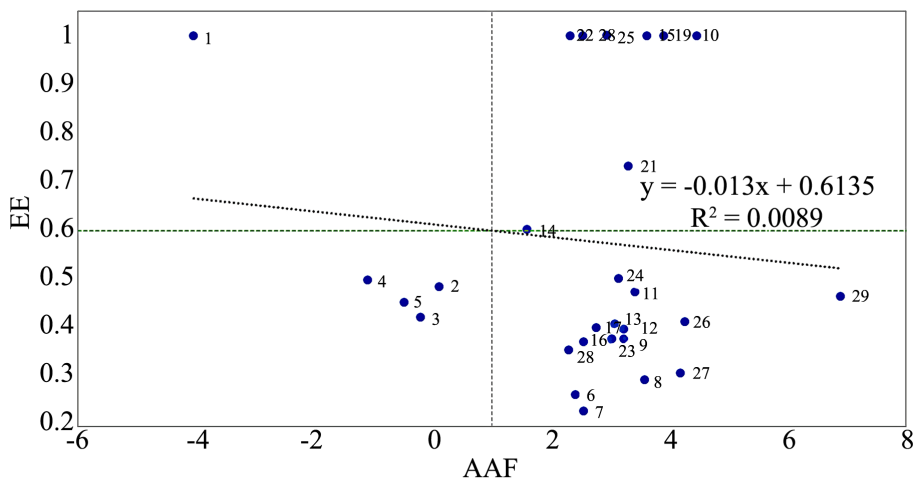

(a)

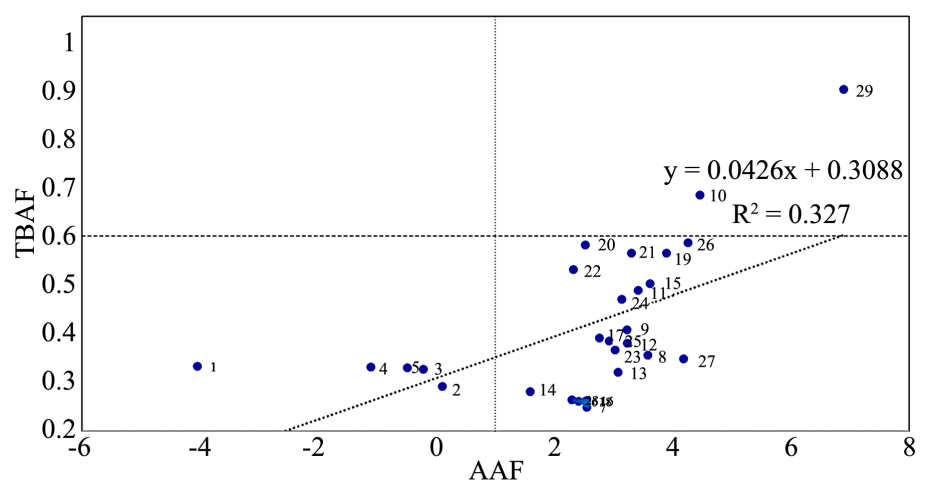

(b)

Figure 5. Scatter plots between AAF, and EE and between AAF, and TBAF. 
In addition, we investigated the correlation coefficients between pairs of TBAF, EE, and logarithms of variables, AAF, AO, L, VA, SW, and $\mathrm{CO}_{2}$. Results in Table 5 reconfirm the positive relationship between EE and TBAF. However, except for $\mathrm{L}$ and $\mathrm{CO}_{2}$, both has a negative impact on TBAF and $\mathrm{EE}$, the rest of variables in the study have inconsistent effects on EE and TBAF. For examples, agriculture and forest area has a positive impact on TBAF but not on EE, or area for other use has a negative impact on EE but its impact on TBAF is not clear. Therefore, to further identify the relationships among variables, we constructed a regression model shown in Equations (18)-(20).

$$
\begin{gathered}
\mathrm{TBAF}=\alpha_{0}+\alpha_{1} \mathrm{EE}+\alpha_{2} \mathrm{LAF}+\varepsilon_{1} \\
\mathrm{TBAF}=\beta_{0}+\beta_{1} \mathrm{LAF}+\beta_{2} \mathrm{LCO}_{2}+\beta_{3} \mathrm{LAO}+\beta_{4} \mathrm{LL}+\beta_{5} \mathrm{LVA}+\beta_{6} \mathrm{LSW}+\varepsilon_{2} \\
\mathrm{TBAF}=\gamma_{0}+\gamma_{1} \mathrm{LAF}+\gamma_{2} \mathrm{LCO}_{2}+\gamma_{3} \mathrm{LAO}+\varepsilon_{3}
\end{gathered}
$$

Equation (18) examines the impact of EE on TBAF. Agriculture and forest area was not included in the estimation of EE, therefore, we added LAF in Equation (18) to test its impact on TBAF. $\varepsilon_{i}, i=1 \sim 3$ is error terms. Equation (19) also investigates the impact of $\mathrm{EE}$ on TBAF, but $\mathrm{EE}$ is replaced with input and output variables in the estimation of EE, i.e. $\mathrm{CO}_{2}, \mathrm{AO}, \mathrm{L}, \mathrm{VA}$, and SW. Note that in Table 5 we observed there existed an issue of collinearity among $\mathrm{CO}_{2}, \mathrm{~L}$, and $\mathrm{VA}$ and that the relation between SW and EE was not significant. Therefore, we kept $\mathrm{CO}_{2}$ that concerns the ecosystem the most and removed L, VA, and SW from Equation (19) and became Equation (20). Results from Equations (18) \& (20) will be our focus of discussion. The Censored Tobit Regression Model and Newton-Raphson optimization are utilized to estimate the coefficient of the regression model. Regression results are shown in Table 6. Results in Equation (18) indicated that every $1 \%$ improvement in environment efficiency enhances TBAF values by $0.238 \%$. Agriculture and forest areas promote TBAF values. The same observation can be seen from results of Equation (20). Every $1 \%$ increase in the input of agriculture and forest areas increases TBAF values by $0.070 \%$.

Table 5. Correlation coefficients between EE, TBAF, AAF, AO, SW, VA, and $\mathrm{CO}_{2}$.

\begin{tabular}{ccccccccc}
\hline & TBAF & EE & LAF & LAO & LL & LVA & LSW & $\mathrm{LCO}_{2}$ \\
\hline TBAF & 1 & $0.467^{* *}$ & $0.639^{* *}$ & -0.278 & $-0.759^{* * *}$ & $-0.689^{* * *}$ & $-0.567^{* *}$ & $-0.630^{* *}$ \\
EE & $0.364^{*}$ & 1 & -0.054 & $-0.604^{* * *}$ & $-0.677^{* * *}$ & $0.524^{* * *}$ & 0.424 & $-0.407^{* * *}$ \\
LAF & $0.572^{* * *}$ & -0.095 & 1 & $-0.472^{* *}$ & $-0.327^{*}$ & -0.248 & $-0.354^{*}$ & -0.181 \\
LAO & -0.168 & $-0.468^{* *}$ & $-0.651^{* *}$ & 1 & $0.444^{* * *}$ & $0.465^{* *}$ & 0.149 & $0.483^{* * *}$ \\
LL & $-0.813^{* * *}$ & $-0.600^{* *}$ & -0.291 & $0.429^{*}$ & 1 & $0.933^{* * *}$ & $0.670^{* * *}$ & $0.825^{* * *}$ \\
LVA & $-0.775^{* * *}$ & $0.511^{* * *}$ & -0.224 & $0.452^{* *}$ & $0.969^{* * *}$ & 1 & $0.503^{* * *}$ & $0.940^{* * *}$ \\
LSW & $-0.736^{* * *}$ & 0.38 & $-0.458^{* * *}$ & 0.206 & $0.730^{* * *}$ & $0.595^{* * *}$ & 1 & $0.386^{* *}$ \\
$\mathrm{LCO}_{2}$ & $-0.711^{* * *}$ & $-0.399^{* *}$ & -0.105 & $0.650^{* * *}$ & $0.894^{* * *}$ & $0.956^{* * *}$ & $0.501^{* * *}$ & 1 \\
\hline
\end{tabular}

Note: The upper right corner and the lower left corner are the Spearman's and Pearson's coefficients, respectively. ${ }^{* * *},{ }^{* *}$ and ${ }^{*}$ denotes significance at the $1 \%, 5 \%$ and $10 \%$ levels, respectively. Data is prepared by this study. 
Table 6. Results of the regression model to test the impact of EE on TBAF.

\begin{tabular}{|c|c|c|c|}
\hline & TBAF in Equation (18) & TBAF in Equation (19) & TBAF in Equation (20) \\
\hline Constant & $\begin{array}{c}0.159^{* * *} \\
(2.762)\end{array}$ & $\begin{array}{c}1.131^{* * *} \\
(3.688)\end{array}$ & $\begin{array}{c}1.032^{* * *} \\
(4.999)\end{array}$ \\
\hline $\mathrm{EE}$ & $\begin{array}{c}0.238^{\star * \star} \\
(3.123)[1.009]\end{array}$ & NA & NA \\
\hline LAF & $\begin{array}{c}0.047^{* * *} \\
(4.480)[1.009]\end{array}$ & $\begin{array}{c}0.070^{\star * *} \\
(4.511)[7.759]\end{array}$ & $\begin{array}{c}0.077^{\star * *} \\
(7.277)[3.489]\end{array}$ \\
\hline $\mathrm{LCO}_{2}$ & & $\begin{array}{c}-0.020 \\
(-0.490)[17.314]\end{array}$ & $\begin{array}{c}-0.033^{* *} \\
(-2.021)[2.679]\end{array}$ \\
\hline LAO & & $\begin{array}{c}-0.120^{* * *} \\
(-2.999)[8.199]\end{array}$ & $\begin{array}{c}-0.135^{\star * *} \\
(-4.405)[4.590]\end{array}$ \\
\hline LL & & $\begin{array}{c}0.005 \\
(0.072)[49.904]\end{array}$ & NA \\
\hline LVA & & $\begin{array}{c}-0.020 \\
(-0.248)[70.491]\end{array}$ & NA \\
\hline LSW & & $\begin{array}{c}-0.017 \\
(-0.390)[5.137]\end{array}$ & NA \\
\hline Maximum Likelihood & 18.315 & 35.892 & 35.668 \\
\hline
\end{tabular}

Note: 1 . Numbers in parentheses are $Z$ values. ${ }^{* *}$, ${ }^{* *}$ and ${ }^{*}$ denotes significance at the $1 \%, 5 \%$ and $10 \%$ levels respectively. 2. Numbers in brackets are variance inflation faction (VIF). VIF $>10$, i.e. $R^{2}>0.9$, suggesting there exists collinearity between variances. Data is prepared by this study.

When we replaced $\mathrm{EE}$ with $\mathrm{CO}_{2}$ and $\mathrm{AO}$, it is observed that both have a negative impact on TBAF. In fact, $\mathrm{AO}$ influences TBAF to a greater extent than $\mathrm{CO}_{2}$ emissions. It is suggested that current urban landscape of Taichung does not consider the ecosystem attentively enough that the ecological effectiveness is compromised by human activities. We show values of EE, TBAF, and percentages of agriculture and forest area (PAF) of individual districts in the geographic maps of Taichung in Figures 6-9. To summarize results from Table 5 \& Table 6 and Figures 6-9, we observed that $\mathrm{EE}$ and TBAF can be improved simultaneously but this conclusion is grounded only when $\mathrm{CO}_{2}$ emissions and $\mathrm{AO}$ input are reduced under the same level of economic activities, i.e. value-added. Agriculture and forest areas improve TBAF, but do not have a significant impact on environmental efficiency. Thus, this city requires attention on resource depletion from the water and electricity consumptions and the wellbeing of the ecosystem, such as a better vegetation structure and water permeability so that the efficiency and ecological value of the area can be both improved.

\section{Empirical Results and Discussions}

This research aims at investigating efficiency from the perspective of urban ecology. To this end, we establish an ecological effectiveness evaluation system, Taiwan Biotope Area Factor which measures the quality of an urban area for protection of living species and the landscape. A bad output data envelopment 


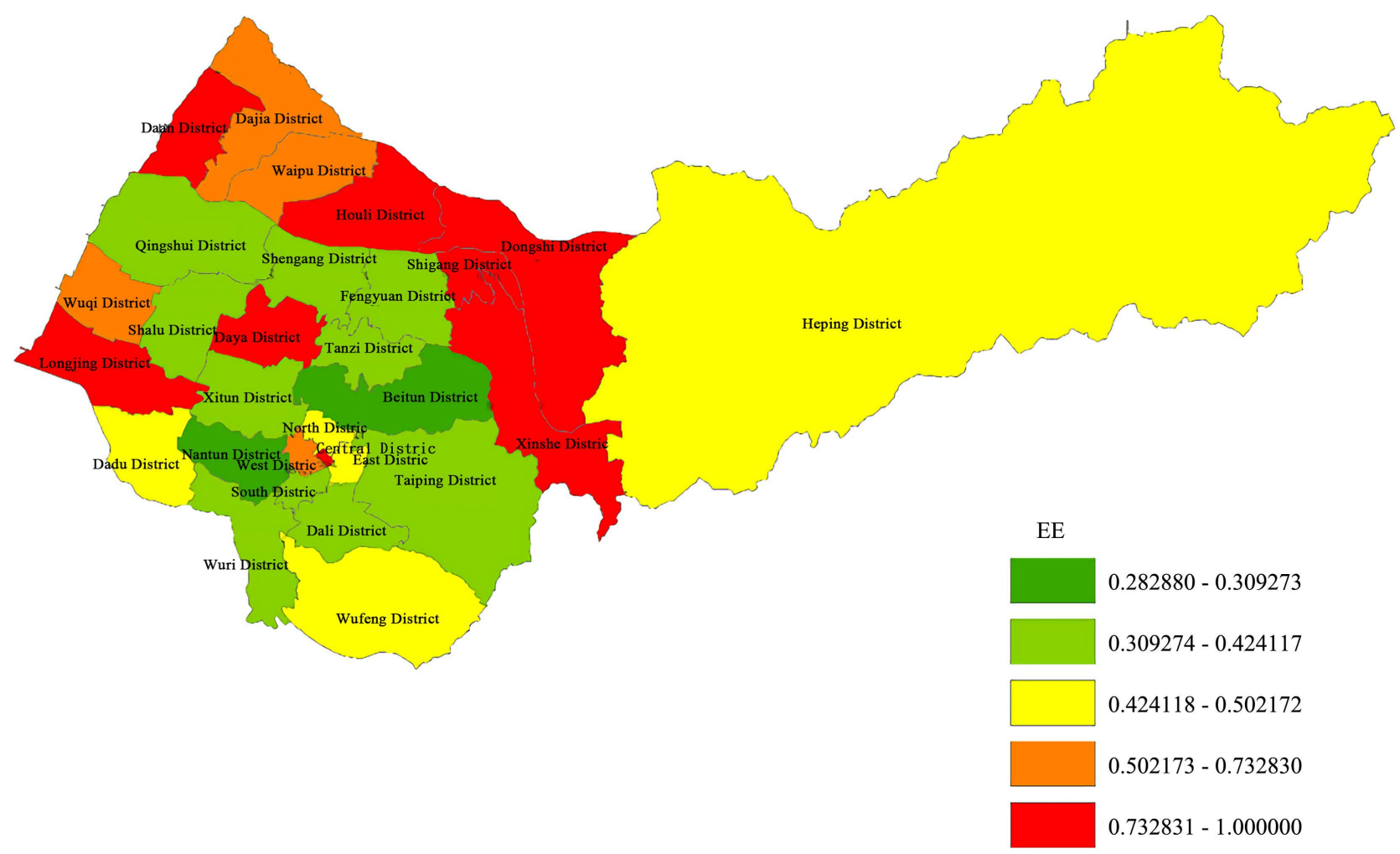

Figure 6. Environmental efficiency values of the 29 Districts in Taichung.

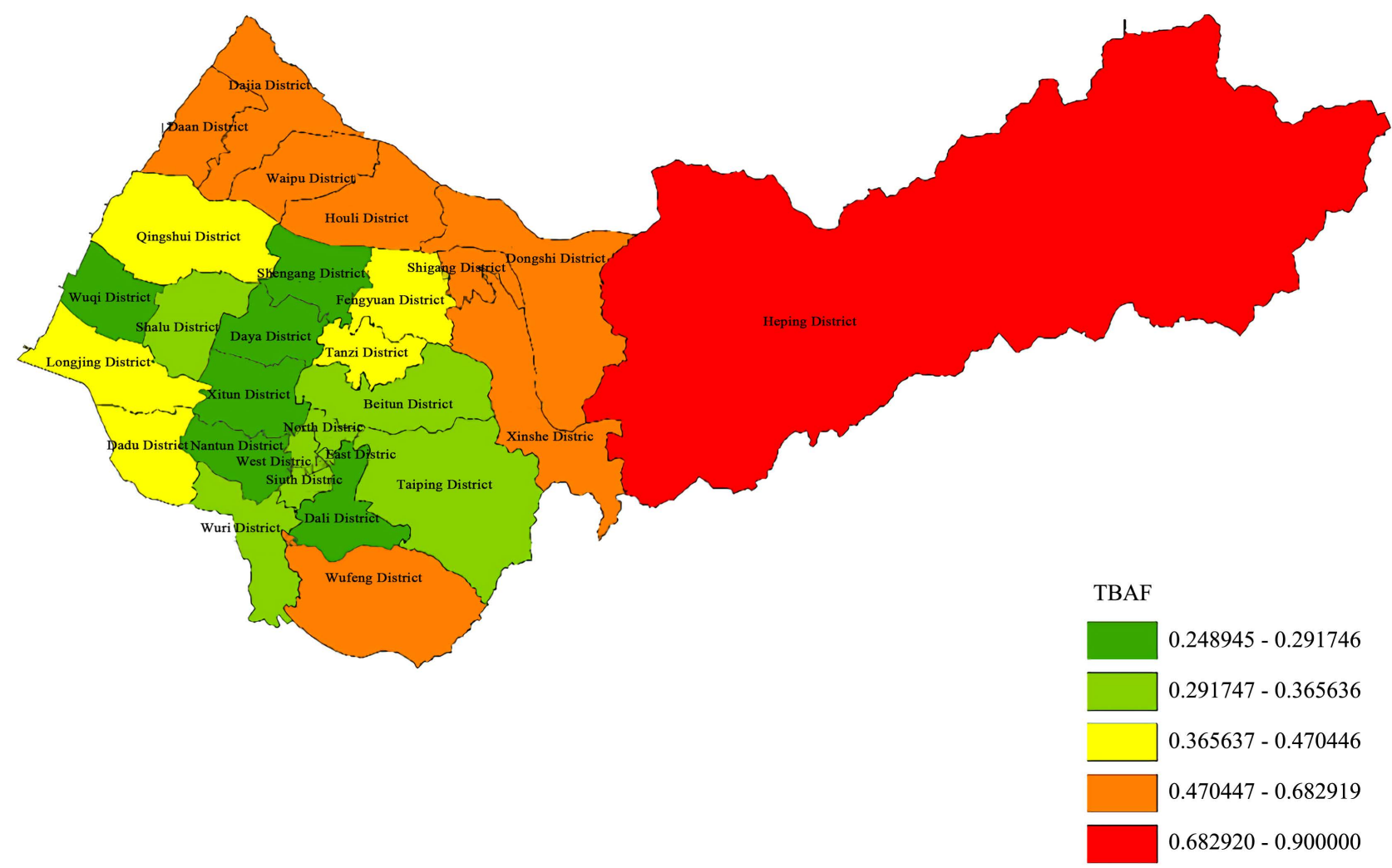

Figure 7. TBAF values of the 29 districts in Taichung. 


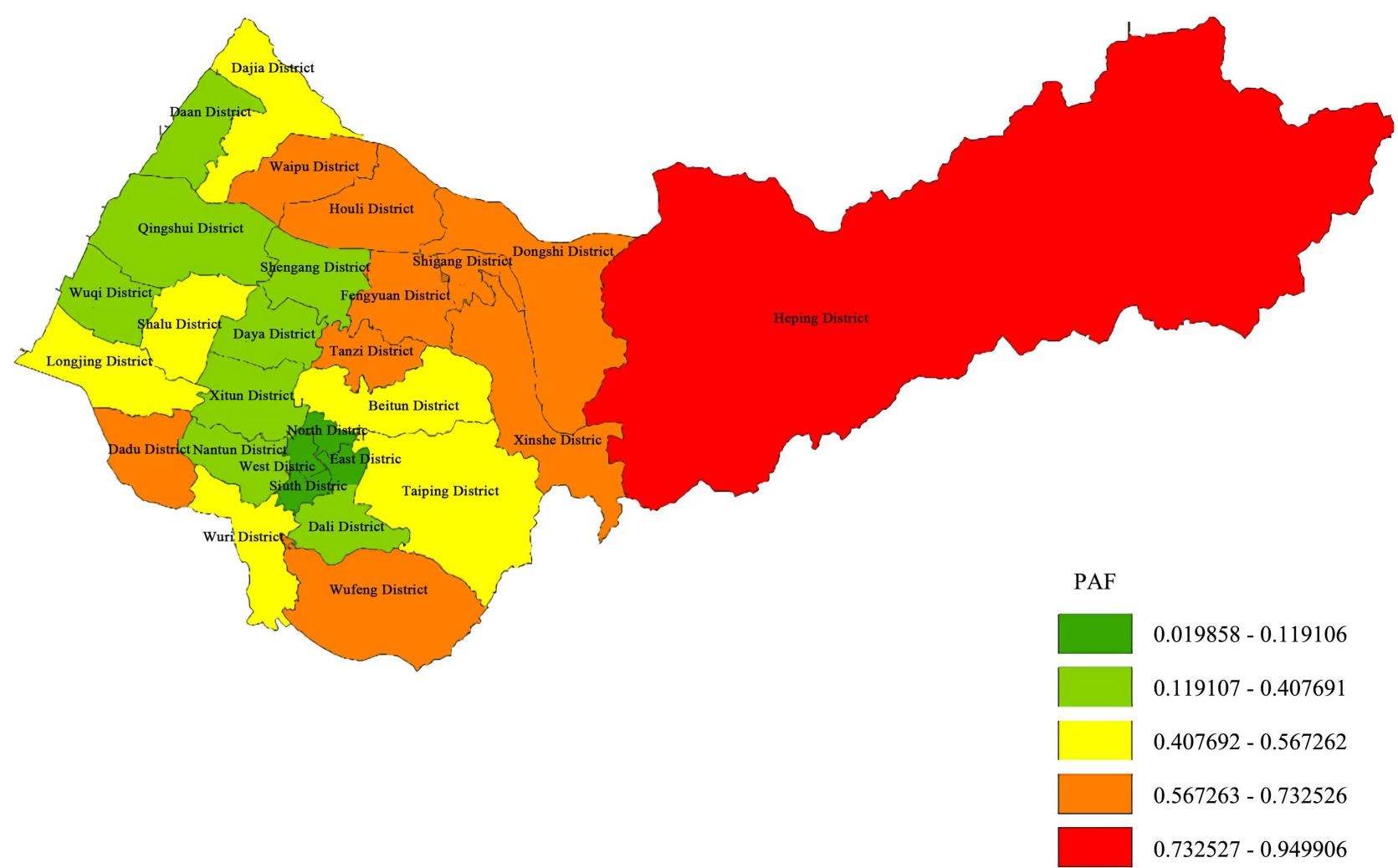

Figure 8. Percentages of agriculture and forest area (PAF) of the 29 districts in Taichung.

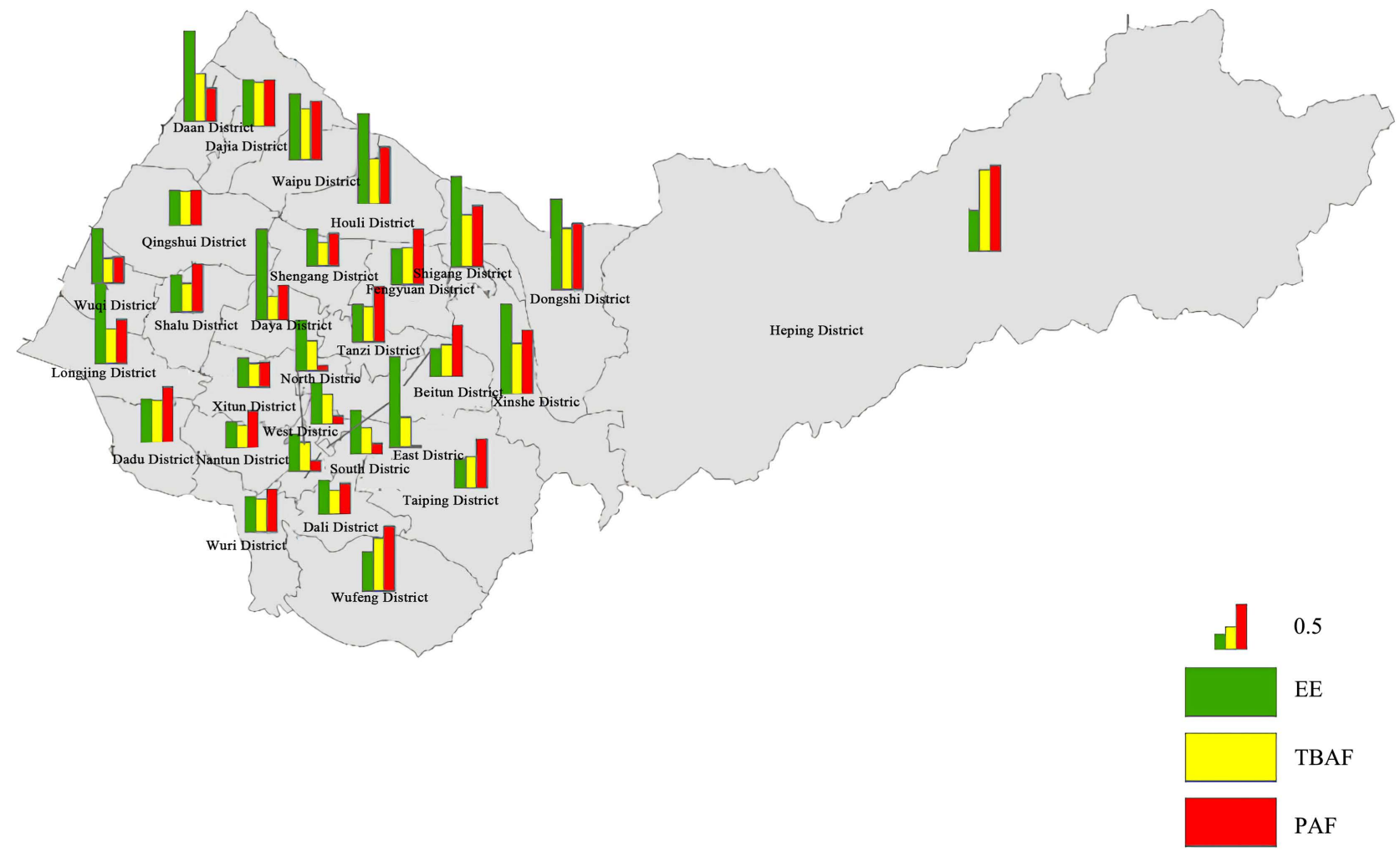

Figure 9. Comparison of EE, TBAF, and percentage of agricultural and forest area (PAF) of the 29 districts in Taichung. 
analysis which considers economic, social, and environmental factors is constructed to evaluate environmental efficiency. A censored regression model is then conducted to examine the relationship between environmental efficiency and Taiwan Biotope Area Factor. Key empirical results are summarized as below: 1) Typical efficiency evaluation without considering the external diseconomies, $\mathrm{CO}_{2}$ emissions in our research, overestimates resource utilization in the context of urban ecology. The average environmental efficiency in the city where we conducted the empirical studies was 0.58 suggesting a $42 \%$ of room of improvement is required to achieve full efficiency in the utilization of resources; 2) Although increasing agricultural and forest area enhances the ecological effectiveness of a region, it does not improve environmental efficiency because the area does not improve labor employment nor social welfare. That is, the productivity of agricultural and forest area is inefficient. Therefore, a trade-off exists between human developments and the quality of the ecosystem upon which human developments are simultaneously dependent; 3) Environmental efficiency and ecological value of a region can be improved simultaneously, however, it can be achieved only under the circumstances of reduced $\mathrm{CO}_{2}$ emissions and a more environment centric consideration in urban landscape planning for commercial, industrial, and residential areas.

Main contributions of this research lie in: 1) providing a comprehensive and structured framework to evaluate environmental efficiency which considers external diseconomies and establishing an ecological effectiveness evaluation system for the metropolitan areas in Taiwan; and 2) providing policymakers with empirical results to examine each individual district in Taichung enabling them to adjust resource allocation and plan for urban landscape accordingly.

There are several research constraints in this research. First, we were unable to obtain data of capital stock which could be used to examine the impact of machinery or technology on environmental efficiency. Second, there were eight districts out of 29 districts in Taichung lacked individual data for water consumption. Therefore, in the empirical studies, the water consumption for these eight districts was calculated by distributing the total water consumption of the eight districts according to the percentage of population in each district. Third, being confined by the size of our sample, we adopted only four social welfare variables out of many social factors and combined them into one collective index in the empirical studies. Our proposed methodology is established with the aim of continuously monitoring in compliance with national policies regarding sustainable development. For future research, we propose to expand research region and employ the meta-frontier data envelopment analysis which allows us to group cities or districts according to different attributes, for instance, levels of urbanization of an area and then compare environmental efficiency and biotope area factor across groups.

\section{Acknowledgements}

This project is sponsored by the Ministry of Science and Technology, Taiwan 
(MOST 108-2420-H-029-003).

\section{Conflicts of Interest}

The authors declare no conflicts of interest regarding the publication of this paper.

\section{References}

Bai, Y., Deng, X., Jiang, S., Zhang, Q., \& Wang, Z. (2018). Exploring the Relationship between Urbanization and Urban Eco-Efficiency: Evidence from Prefecture-Level Cities in China. Journal of Cleaner Production, 195, 1487-1496.

https://doi.org/10.1016/j.jclepro.2017.11.115

Chang, Y. T., Zhang, N., Danao, D., \& Zhang, N. (2013). Environmental Efficiency Analysis of Transportation System in China: A Non-Radial DEA Approach. Energy Policy, 58, 277-283. https://doi.org/10.1016/j.enpol.2013.03.011

Charnes, A., Cooper, W. W., \& Rhodes, E. (1978). Measuring the Efficiency of Decision Making Units. European Journal of Operational Research, 2, 429-444. https://doi.org/10.1016/0377-2217(78)90138-8

Chuang, C., \& Wu, C. (2006). Measuring the Efficiency of the Credit Department of Farmers' Associations in Taiwan: An Application of Data Envelopment Analysis with Undesirable Factors. Soochow Journal of Economics and Business, 52, 1-25.

Dramstad, W., Olson, J. D., \& Forman, R. T. (1996). Landscape Ecology Principles in Landscape Architecture and Land-Use Planning. Washington DC: Island Press.

el-Baghdadi, O., \& Desha, C. (2017). Conceptualizing a Biophilic Services Model for Urban Areas. Urban Forestry \& Urban Greening, 27, 399-408.

https://doi.org/10.1016/j.ufug.2016.10.016

Faere, R., Grosskopf, S. Lovell, C. A. K., \& Pasurka, C. (1989). Multilateral Productivity Comparisons When Some Outputs Are Undesirable: A Nonparametric Approach. The Review of Economics and Statistics, 71, 90-98. https://doi.org/10.2307/1928055

Forman, R. (2014). Urban Ecology: Science of Cities. New York: Cambridge University Press.

Forman, R. T. T., \& Godron, M. (1986). Landscape Ecology. New York, NY: John Wiley and Sons Ltd.

Liu, W., Zhan, J., Wang, C., Li, S., \& Zhang, F. (2018). Environmentally Sensitive Productivity Growth of Industrial Sectors in the Pearl River Delta. Resources, Conservation and Recycling, 139, 50-63. https://doi.org/10.1016/j.resconrec.2018.07.017

Lozano, S., \& Gutiérrez, E. (2011). Slacks-Based Measure of Efficiency of Airports with Airplanes Delays as Undesirable Outputs. Computers \& Operations Research, 38, 131-139. https://doi.org/10.1016/j.cor.2010.04.007

Mills, W. P., \& Rott, A. (2020). Vertical Life: Impact of Roof Height on Beetle Diversity and Abundance on Wildflower Green Roofs. Journal of Urban Ecology, 6, 1-8. https://doi.org/10.1093/jue/juaa017

National Oceanic and Atmospheric Administration (NOAA) (2018). State of the Climate: Global Climate Report-Annual 2017. https://www.ncdc.noaa.gov/sotc/global/201713

Peng, J., Zhao, H., \& Liu, Y. (2017). Urban Ecological Corridors Construction: A Review. Acta Ecologica Sinica, 37, 23-30. https://doi.org/10.1016/j.chnaes.2016.12.002

Portela, M. S., Thanassoulis, E., \& Simpson, G. (2004). Negative data in DEA: A Direc- 
tional Distance Approach Applied to Bank Branches. Journal of the Operational Research Society, 55, 1111-1121. https://doi.org/10.1057/palgrave.jors.2601768

Rahman, M. T., Nielsen, R., Khan, M. A., \& Asmild, M. (2019). Efficiency and Production Environmental Heterogeneity in Aquaculture: A Meta-Frontier DEA Approach. Aquaculture, 509, 140-148. https://doi.org/10.1016/j.aquaculture.2019.05.002

Seiford, L. M., \& Zhu, J. (2002). Modeling Undesirable Factors in Efficiency Evaluation. European Journal of Operational Research, 142, 16-20. https://doi.org/10.1016/S0377-2217(01)00293-4

Sukopp, H., \& Weiler, S. (1988). Biotope Mapping and Nature Conservation Strategies in Urban Areas of the Federal Republic of Germany. Landscape and Urban Planning, 15, 39-58. https://doi.org/10.1016/0169-2046(88)90015-1

Taskin, F., \& Zaim, O. (2001). The Role of International Trade on Environmental Efficiency: A DEA Approach. Economic Modelling, 18, 1-17. https://doi.org/10.1016/S0264-9993(00)00025-0

Thuring, C., \& Grant, G. (2016). The Biodiversity of Temperate Extensive Green Roofs-A Review of Research and Practice. Israel Journal of Ecology \& Evolution, 62, 4-57. https://doi.org/10.1080/15659801.2015.1091190

Tone, K. (2001). A Slacks-Based Measure of Efficiency in Data Envelopment Analysis. European Journal of Operational Research, 130, 498-509. https://doi.org/10.1016/S0377-2217(99)00407-5

Tone, K. (2002). A Slacks-Based Measure of Super-Efficiency in Data Envelopment Analysis. European Journal of Operational Research, 143, 32-41. https://doi.org/10.1016/S0377-2217(01)00324-1

Tone, K. (2003). Dealing with Undesirable Outputs in DEA: A Slacks-Based Measure (SBM) Approach. GRIPS Research Report Series 2003. Tokyo: National Graduate Institute for Policy Studies.

Wang, C., Zhan, J., Bai, Y., Chu, X., \& Zhang, F. (2019). Measuring Carbon Emission Performance of Industrial Sectors in the Beijing-Tianjin-Hebei Region, China: A Stochastic Frontier Approach. Science of the Total Environment, 685, 786-794. https://doi.org/10.1016/j.scitotenv.2019.06.064

Wang, K., Yu, S., \& Zhang, W. (2013). China's Regional Energy and Environmental Efficiency: A DEA Window Analysis Based Dynamic Evaluation. Mathematical and Computer Modelling, 58, 1117-1127. https://doi.org/10.1016/j.mcm.2011.11.067

Wang, L., Toppinen, A., \& Juslin, H. (2014). Use of Wood in Green Building: A Study of Expert Perspectives from the UK. Journal of Cleaner Production, 65, 350-361. https://doi.org/10.1016/j.jclepro.2013.08.023

Yilmaz, B., Gulez, S., \& Kaya, L. G. (2010). Mapping of Biotopes in Urban Areas: A Case Study of the City of Bartin and Its Environs, Turkey. Scientific Research and Essays, 5, 352-365.

Zhang, J., Li, H., Xia, B., \& Skitmore, M. (2018). Impact of Environment Regulation on the Efficiency of Regional Construction Industry: A 3-Stage Data Envelopment Analysis (DEA). Journal of Cleaner Production, 200, 770-780.

https://doi.org/10.1016/j.jclepro.2018.07.189

Zhou, Y., Xing, X., Fang, K., Liang, D., \& Xu, C. (2013). Environmental Efficiency Analysis of Power Industry in China Based on an Entropy SBM Model. Energy Policy, 57, 68-75. https://doi.org/10.1016/j.enpol.2012.09.060 


\section{Appendix}

Table A1. Values of EE, output and input variables of the 29 districts in Taichung.

\begin{tabular}{|c|c|c|c|c|c|}
\hline District & DMU & Original value & Target value & Slacks & Room of improvement \\
\hline \multirow{6}{*}{ Central } & $\mathrm{EE}$ & 1 & NA & NA & NA \\
\hline & $\mathrm{L}$ & 15,187 & 15,187 & 0 & $0.00 \%$ \\
\hline & $\mathrm{AO}$ & 0.8258 & 0.8258 & 0 & $0.00 \%$ \\
\hline & $\mathrm{CO}_{2}$ & 911,090 & 911,090 & 0 & $0.00 \%$ \\
\hline & SW & 222 & 222 & 0 & $0.00 \%$ \\
\hline & VA & 451,352 & 451,352 & 0 & $0.00 \%$ \\
\hline \multirow{6}{*}{ East } & $\mathrm{EE}$ & 0.4857 & NA & NA & NA \\
\hline & $\mathrm{L}$ & 27,084 & 25,055 & -2029 & $-7.49 \%$ \\
\hline & $\mathrm{AO}$ & 7.2111 & 1.3624 & -5.8487 & $-81.11 \%$ \\
\hline & $\mathrm{CO}_{2}$ & $1,805,354$ & $1,503,059$ & $-302,296$ & $-16.74 \%$ \\
\hline & SW & 366 & 366 & 0 & $0.00 \%$ \\
\hline & VA & 594,607 & 744,613 & 150,006 & $25.23 \%$ \\
\hline \multirow{6}{*}{ South } & $\mathrm{EE}$ & 0.4241 & NA & NA & NA \\
\hline & $\mathrm{L}$ & 38,227 & 29,211 & -9016 & $-23.59 \%$ \\
\hline & $\mathrm{AO}$ & 4.9831 & 1.5884 & -3.3948 & $-68.13 \%$ \\
\hline & $\mathrm{CO}_{2}$ & $3,032,948$ & $1,752,386$ & $-1,280,562$ & $-42.22 \%$ \\
\hline & SW & 338 & 427 & 88.5925 & $26.21 \%$ \\
\hline & VA & 868,129 & 868129 & 0 & $0.00 \%$ \\
\hline \multirow{6}{*}{ West } & $\mathrm{EE}$ & 0.4991 & NA & NA & NA \\
\hline & $\mathrm{L}$ & 76,274 & 61,920 & $-14,354$ & $-18.82 \%$ \\
\hline & $\mathrm{AO}$ & 4.7813 & 3.367 & -1.4143 & $-29.58 \%$ \\
\hline & $\mathrm{CO}_{2}$ & $3,928,042$ & $3,714,692$ & $-213,350$ & $-5.43 \%$ \\
\hline & SW & 305 & 904 & 600 & $196.66 \%$ \\
\hline & VA & $1,840,252$ & $1,840,252$ & 0 & $0.00 \%$ \\
\hline \multirow{6}{*}{ North } & $\mathrm{EE}$ & 0.4547 & NA & NA & NA \\
\hline & $\mathrm{L}$ & 63,864 & 48,410 & -15454 & $-24.20 \%$ \\
\hline & $\mathrm{AO}$ & 5.3989 & 2.6323 & -2.7666 & $-51.24 \%$ \\
\hline & $\mathrm{CO}_{2}$ & $4,322,299$ & $2,904,169$ & $-1,418,130$ & $-32.81 \%$ \\
\hline & SW & 388 & 707 & 319 & $82.29 \%$ \\
\hline & VA & $1,438,720$ & $1,438,720$ & 0 & $0.00 \%$ \\
\hline \multirow[b]{2}{*}{ Xitun } & $\mathrm{EE}$ & 0.2655 & NA & NA & NA \\
\hline & $\mathrm{L}$ & 166,448 & 166,448 & 0 & $0.00 \%$ \\
\hline
\end{tabular}




\section{Continued}

\begin{tabular}{|c|c|c|c|c|c|}
\hline & $\mathrm{AO}$ & 24.9543 & 15.1469 & -9.8074 & $-39.30 \%$ \\
\hline & $\mathrm{CO}_{2}$ & $28,981,048$ & $15,150,253$ & $-13,830,796$ & $-47.72 \%$ \\
\hline & SW & 269 & 2189 & 1920 & $715.20 \%$ \\
\hline & VA & $5,622,042$ & $5,622,042$ & 0 & $0.00 \%$ \\
\hline \multirow{6}{*}{ Nantun } & $\mathrm{EE}$ & 0.2309 & NA & NA & NA \\
\hline & $\mathrm{L}$ & 97,621 & 92,135 & -5486 & $-5.62 \%$ \\
\hline & $\mathrm{AO}$ & 16.6758 & 5.0099 & -11.6659 & $-69.96 \%$ \\
\hline & $\mathrm{CO}_{2}$ & $6,986,038$ & $5,527,289$ & $-1,458,750$ & $-20.88 \%$ \\
\hline & SW & 183 & 1346 & 1163 & $636.01 \%$ \\
\hline & VA & $2,738,209$ & $2,738,209$ & 0 & $0.00 \%$ \\
\hline \multirow{6}{*}{ Beitun } & $\mathrm{EE}$ & 0.296 & NA & NA & NA \\
\hline & $\mathrm{L}$ & 76,929 & 55,992 & $-20,937$ & $-27.22 \%$ \\
\hline & $\mathrm{AO}$ & 23.4511 & 3.0447 & -20.4064 & $-87.02 \%$ \\
\hline & $\mathrm{CO}_{2}$ & $4,824,528$ & $3,359,065$ & $-1,465,463$ & $-30.38 \%$ \\
\hline & SW & 374 & 818 & 444 & $118.77 \%$ \\
\hline & VA & $1,664,075$ & $1,664,075$ & 0 & $0.00 \%$ \\
\hline \multirow{6}{*}{ Fengyuan } & $\mathrm{EE}$ & 0.3786 & NA & NA & NA \\
\hline & $\mathrm{L}$ & 55,881 & 49,510 & -6371 & $-11.40 \%$ \\
\hline & $\mathrm{AO}$ & 13.2044 & 2.6922 & -10.5123 & $-79.61 \%$ \\
\hline & $\mathrm{CO}_{2}$ & $3,941,035$ & $2,970,179$ & $-970,856$ & $-24.63 \%$ \\
\hline & SW & 319 & 723 & 404 & $126.44 \%$ \\
\hline & VA & $1,471,422$ & $1,471,422$ & 0 & $0.00 \%$ \\
\hline \multirow{6}{*}{ Dengshi } & $\mathrm{EE}$ & 1 & NA & NA & NA \\
\hline & $\mathrm{L}$ & 8416 & 8416 & 0 & $0.00 \%$ \\
\hline & $\mathrm{AO}$ & 12.1211 & 12.1211 & 0 & $0.00 \%$ \\
\hline & $\mathrm{CO}_{2}$ & 632,336 & 632,336 & 0 & $0.00 \%$ \\
\hline & SW & 234 & 234 & 0 & $0.00 \%$ \\
\hline & VA & $166,017.7$ & $166,017.67$ & 0 & $0.00 \%$ \\
\hline \multirow{6}{*}{ Dajia } & $\mathrm{EE}$ & 0.4751 & NA & NA & NA \\
\hline & $\mathrm{L}$ & 37,341 & 37,341 & 0 & $0.00 \%$ \\
\hline & $\mathrm{AO}$ & 13.975 & 3.8632 & -10.1118 & $-72.36 \%$ \\
\hline & $\mathrm{CO}_{2}$ & $3,919,325$ & $3,792,929$ & $-126,396$ & $-3.22 \%$ \\
\hline & SW & 205 & 472 & 268 & $130.92 \%$ \\
\hline & VA & $1,312,779$ & $1,312,779$ & 0 & $0.00 \%$ \\
\hline
\end{tabular}




\section{Continued}

\begin{tabular}{|c|c|c|c|c|c|}
\hline \multirow{6}{*}{ Qingshui } & $\mathrm{EE}$ & 0.399 & NA & NA & NA \\
\hline & $\mathrm{L}$ & 19,593 & 19,593 & 0 & $0.00 \%$ \\
\hline & $\mathrm{AO}$ & 22.4967 & 1.4845 & -21.0122 & $-93.40 \%$ \\
\hline & $\mathrm{CO}_{2}$ & $2,616,352$ & $1,303,590$ & $-1,312,762$ & $-50.18 \%$ \\
\hline & SW & 206 & 275 & 69.7533 & $33.92 \%$ \\
\hline & VA & 608,716 & 608,716 & 0 & $0.00 \%$ \\
\hline \multirow{6}{*}{ Shalu } & $\mathrm{EE}$ & 0.41 & NA & NA & NA \\
\hline & $\mathrm{L}$ & 27,764 & 27,764 & 0 & $0.00 \%$ \\
\hline & $\mathrm{AO}$ & 17.2011 & 1.9237 & -15.2774 & $-88.82 \%$ \\
\hline & $\mathrm{CO}_{2}$ & $3,041,567$ & $2,016,336$ & $-1,025,230$ & $-33.71 \%$ \\
\hline & SW & 222 & 389 & 167 & $74.89 \%$ \\
\hline & VA & 870,993 & 870,993 & 0 & $0.00 \%$ \\
\hline \multirow{6}{*}{ Wuqi } & $\mathrm{EE}$ & 0.6033 & NA & NA & NA \\
\hline & $\mathrm{L}$ & 35,835 & 35,835 & 0 & $0.00 \%$ \\
\hline & $\mathrm{AO}$ & 8.7559 & 5.6549 & -3.101 & $-35.42 \%$ \\
\hline & $\mathrm{CO}_{2}$ & $7,988,695$ & $5,289,885$ & $-2,698,810$ & $-33.78 \%$ \\
\hline & SW & 211 & 376 & 165 & $78.05 \%$ \\
\hline & VA & $1,475,551$ & $1,475,551$ & 0 & $0.00 \%$ \\
\hline \multirow{6}{*}{ Houli } & $\mathrm{EE}$ & 1 & NA & NA & NA \\
\hline & $\mathrm{L}$ & 23,115 & 23,115 & 0 & $0.00 \%$ \\
\hline & $\mathrm{AO}$ & 14.1691 & 14.1691 & 0 & $0.00 \%$ \\
\hline & $\mathrm{CO}_{2}$ & $13,387,863$ & $13,387,863$ & 0 & $0.00 \%$ \\
\hline & SW & 79.6683 & 79.6683 & 0 & $0.00 \%$ \\
\hline & VA & $1,410,730$ & $1,410,730$ & 0 & $0.00 \%$ \\
\hline \multirow{6}{*}{ Shengang } & $\mathrm{EE}$ & 0.3729 & NA & NA & NA \\
\hline & $\mathrm{L}$ & 43,229 & 43,229 & 0 & $0.00 \%$ \\
\hline & $\mathrm{AO}$ & 19.1474 & 2.6278 & -16.5196 & $-86.28 \%$ \\
\hline & $\mathrm{CO}_{2}$ & $3,151,915$ & $2,828,211$ & $-323,704$ & $-10.27 \%$ \\
\hline & SW & 214 & 620 & 406 & $189.43 \%$ \\
\hline & VA & $1,315,455$ & $1,315,455$ & 0 & $0.00 \%$ \\
\hline \multirow{4}{*}{ Tanzi } & $\mathrm{EE}$ & 0.4019 & NA & NA & NA \\
\hline & $\mathrm{L}$ & 56,431 & 55,998 & -433 & $-0.77 \%$ \\
\hline & $\mathrm{AO}$ & 8.9093 & 3.045 & -5.8644 & $-65.82 \%$ \\
\hline & $\mathrm{CO}_{2}$ & $6,506,200$ & $3,359,417$ & $-3,146,782$ & $-48.37 \%$ \\
\hline
\end{tabular}




\section{Continued}

\begin{tabular}{|c|c|c|c|c|c|}
\hline & SW & 306 & 818 & 512 & $167.20 \%$ \\
\hline & VA & $1,664,250$ & $1,664,250$ & 0 & $0.00 \%$ \\
\hline \multirow{6}{*}{ Daya } & $\mathrm{EE}$ & 1 & NA & NA & NA \\
\hline & $\mathrm{L}$ & 64,061 & 64,061 & 0 & $0.00 \%$ \\
\hline & $\mathrm{AO}$ & 17.8359 & 17.8359 & 0 & $0.00 \%$ \\
\hline & $\mathrm{CO}_{2}$ & $16,002,998$ & $16,002,998$ & 0 & $0.00 \%$ \\
\hline & SW & 365 & 365 & 0 & $0.00 \%$ \\
\hline & VA & $3,493,701$ & $3,493,701$ & 0 & $0.00 \%$ \\
\hline \multirow{6}{*}{ Xinshe } & $\mathrm{EE}$ & 1 & NA & NA & NA \\
\hline & $\mathrm{L}$ & 3606 & 3606 & 0 & $0.00 \%$ \\
\hline & $\mathrm{AO}$ & 14.0408 & 14.0408 & 0 & $0.00 \%$ \\
\hline & $\mathrm{CO}_{2}$ & 591,682 & 591,682 & 0 & $0.00 \%$ \\
\hline & SW & 162 & 162 & 0 & $0.00 \%$ \\
\hline & VA & 72,682 & 72,682 & 0 & $0.00 \%$ \\
\hline \multirow{6}{*}{ Shigang } & $\mathrm{EE}$ & 1 & NA & NA & NA \\
\hline & $\mathrm{L}$ & 2732 & 2732 & 0 & $0.00 \%$ \\
\hline & $\mathrm{AO}$ & 3.1665 & 3.1665 & 0 & $0.00 \%$ \\
\hline & $\mathrm{CO}_{2}$ & 337,827 & 337,827 & 0 & $0.00 \%$ \\
\hline & SW & 80.8377 & 80.8377 & 0 & $0.00 \%$ \\
\hline & VA & 65,205 & 65,205 & 0 & $0.00 \%$ \\
\hline \multirow{6}{*}{ Waipu } & $\mathrm{EE}$ & 0.7328 & NA & NA & NA \\
\hline & $\mathrm{L}$ & 8709 & 8709 & 0 & $0.00 \%$ \\
\hline & $\mathrm{AO}$ & 8.033 & 4.0995 & -3.9335 & $-48.97 \%$ \\
\hline & $\mathrm{CO}_{2}$ & 805,601 & 756,488 & $-49,113$ & $-6.10 \%$ \\
\hline & SW & 172 & 172 & 0 & $0.00 \%$ \\
\hline & VA & 246,516 & 246,516 & 0 & $0.00 \%$ \\
\hline \multirow{6}{*}{ Daan } & $\mathrm{EE}$ & 1 & NA & NA & NA \\
\hline & $\mathrm{L}$ & 4339 & 4339 & 0 & $0.00 \%$ \\
\hline & $\mathrm{AO}$ & 2.8045 & 2.8045 & 0 & $0.00 \%$ \\
\hline & $\mathrm{CO}_{2}$ & 460,528 & 460,528 & 0 & $0.00 \%$ \\
\hline & SW & 98.5976 & 98.5976 & 0 & $0.00 \%$ \\
\hline & VA & 109,241 & 109,241 & 0 & $0.00 \%$ \\
\hline \multirow{2}{*}{ Wuri } & $\mathrm{EE}$ & 0.3795 & NA & NA & NA \\
\hline & $\mathrm{L}$ & 30,669 & 30,669 & 0 & $0.00 \%$ \\
\hline
\end{tabular}




\section{Continued}

\begin{tabular}{|c|c|c|c|c|c|}
\hline & $\mathrm{AO}$ & 16.3266 & 2.1441 & -14.1825 & $-86.87 \%$ \\
\hline & $\mathrm{CO}_{2}$ & $3,415,470$ & $2,243,557$ & $-1,171,913$ & $-34.31 \%$ \\
\hline & SW & 188 & 429 & 240 & $127.59 \%$ \\
\hline & VA & 964,251 & 964,251 & 0 & $0.00 \%$ \\
\hline \multirow{6}{*}{ Dadu } & $\mathrm{EE}$ & 0.5022 & NA & NA & NA \\
\hline & $\mathrm{L}$ & 18,353 & 18,353 & 0 & $0.00 \%$ \\
\hline & $\mathrm{AO}$ & 9.7921 & 1.5941 & -8.198 & $-83.72 \%$ \\
\hline & $\mathrm{CO}_{2}$ & $2,149,063$ & $1,606,095$ & $-542,968$ & $-25.27 \%$ \\
\hline & SW & 217 & 244 & 27.2954 & $12.58 \%$ \\
\hline & VA & 611,480 & 611,480 & 0 & $0.00 \%$ \\
\hline \multirow{6}{*}{ Longjing } & $\mathrm{EE}$ & 1 & NA & NA & NA \\
\hline & $\mathrm{L}$ & 27,308 & 27,308 & 0 & $0.00 \%$ \\
\hline & $\mathrm{AO}$ & 13.1919 & 13.1919 & 0 & $0.00 \%$ \\
\hline & $\mathrm{CO}_{2}$ & $5,218,913$ & $5,218,913$ & 0 & $0.00 \%$ \\
\hline & SW & 97.9698 & 97.9698 & 0 & $0.00 \%$ \\
\hline & VA & $1,549,606$ & $1,549,606$ & 0 & $0.00 \%$ \\
\hline \multirow{6}{*}{ Wufeng } & $\mathrm{EE}$ & 0.4143 & NA & NA & NA \\
\hline & $\mathrm{L}$ & 25,576 & 25,576 & 0 & $0.00 \%$ \\
\hline & $\mathrm{AO}$ & 18.4146 & 3.0718 & -15.3428 & $-83.32 \%$ \\
\hline & $\mathrm{CO}_{2}$ & $2,628,280$ & $2,048,509$ & $-579,771$ & $-22.06 \%$ \\
\hline & SW & 151 & 330 & 180 & $119.12 \%$ \\
\hline & VA & 866,087 & 866,087 & 0 & $0.00 \%$ \\
\hline \multirow{6}{*}{ Taiping } & $\mathrm{EE}$ & 0.3093 & NA & NA & NA \\
\hline & $\mathrm{L}$ & 60,836 & 52,419 & -8417 & $-13.84 \%$ \\
\hline & $\mathrm{AO}$ & 47.6712 & 2.8503 & -44.8209 & $-94.02 \%$ \\
\hline & $\mathrm{CO}_{2}$ & $5,574,354$ & $3,144,666$ & $-2,429,688$ & $-43.59 \%$ \\
\hline & SW & 367 & 766 & 399 & $108.69 \%$ \\
\hline & VA & $1,557,862$ & $1,557,862$ & 0 & $0.00 \%$ \\
\hline \multirow{6}{*}{ Dali } & $\mathrm{EE}$ & 0.3564 & NA & NA & NA \\
\hline & $\mathrm{L}$ & 76,784 & 67,918 & -8866 & $-11.55 \%$ \\
\hline & $\mathrm{AO}$ & 16.2369 & 3.6931 & -12.5438 & $-77.25 \%$ \\
\hline & $\mathrm{CO}_{2}$ & $5,691,133$ & $4,074,471$ & $-1,616,662$ & $-28.41 \%$ \\
\hline & SW & 371 & 992 & 621 & $167.12 \%$ \\
\hline & VA & $2,018,486$ & $2,018,486$ & 0 & $0.00 \%$ \\
\hline
\end{tabular}




\begin{tabular}{cccccc} 
Continued & \multicolumn{5}{c}{} \\
\hline & $\mathrm{EE}$ & 0.4664 & $\mathrm{NA}$ & $\mathrm{NA}$ & $\mathrm{NA}$ \\
\multirow{4}{*}{ Heping } & $\mathrm{L}$ & 1969 & 1969 & 0 & $0.00 \%$ \\
& $\mathrm{AO}$ & 7.3546 & 0.5461 & -6.8085 & $-92.58 \%$ \\
& $\mathrm{CO}$ & $298,812.9797$ & $208,161.905$ & $-90,651.0747$ & $-30.34 \%$ \\
& $\mathrm{SW}$ & 24.4716 & 24.4716 & 0 & $0.00 \%$ \\
& $\mathrm{VA}$ & 74,015 & 74,015 & 0 & $0.00 \%$ \\
\hline
\end{tabular}

Data is prepared by this study. 